\title{
USING A GENRE-BASED APPROACH TO PREPARE UNDERGRADUATE STUDENTS FOR AN ENGLISH THESIS DEFENCE EXAMINATION: AN EXPERIMENTAL STUDY TO ADDRESS THE 'PEDAGOGICAL CONTROVERSY'
}

\author{
Iskandar Abdul Samad \\ Syiah Kuala University \\ iskandar.abdul.samad@unsyiah.ac.id \\ Zifirdaus Adnan* \\ University of New England \\ zadnan@une.edu.au
}

\begin{abstract}
A great deal of research has been conducted on genre based approach, suggesting that it is an important approach. Its importance is also indicated by the fact that it is adopted in the 2004 and 2006 National English Curricula of Indonesian secondary schools. However, the pedagogical benefit of this approach to English language teaching is still controversial. Some research has shown that it is effective to develop language competence, some has not. The fact that since the adoption of this approach in the 2004 Indonesian National Curriculum the quality of Indonesian English language teaching at Indonesian schools has not significantly improved complicates the issue further. The present study was intended to contribute to the debate. It is an experiment to discover whether the approach can help improve the performance of students in university thesis defence examinations. The study was conducted at a university level because of an important practical issue, that is complaints among members of the academic community about the poor performance of undergraduate $(U G)$ students in the thesis defence examination (TDE) event at Indonesian universities especially in Aceh. It was believed that even though students were competent in speaking general English, they were poor in their oral thesis defence performance. This study concludes that, with some conditions, it can help at least in some respects.
\end{abstract}

Keywords: undergraduate students, thesis defence, genre approach

\begin{abstract}
Abstrak
Sudah banyak dilakukan penelitian tentang pendekatan berbasis genre, yang menunjukkan bahwa pendekatan ini penting. Pentingnya pendekatan ini juga diindikasikan oleh kenyataan bahwa pendekatan ini dimasukkan dalam Kurikulum Nasional Indonesia di bidang bahasa Inggris untuk sekolah menengah. Namun, manfaat pedagogis pendekatan ini masih kontroversial karena hasil sebagian riset menunjukkan adanya manfaat, tapi sebagian lain tidak. Kenyataan bahwa tujuan baik dari penggunaan pendekatan ini dalam Kurikulum 2004 dan 2006, yaitu memperbaiki hasil pengajaran bahasa Bahasa Inggris di sekolah-sekolah di Indonesia, belum tercapai secara signifikan, menambah rumitnya kontroversi tersebut. Kajian yang berbentuk eksperimen ini bertujuan untuk memberikan kontribusi pada perdebatan ini dan untuk menguji apakah pengajaran dengan pendekatan ini bermanfaat atau tidak, dengan menggunakan ujian skripsi mahasiswa sebagai objek studi kasus. Dengan kata lain, apakah mahasiswa yang diajar dengan pendekatan ini mendapat hasil yang lebih baik daripada mahasiwa yang tidak. Percobaan ini diadakan pada tingkat universitas karena adanya faktor praktis, yaitu keluhan-keluhan dari staf akademik tentang parahnya prestasi mahasiswa dalam ujian skripsi dalam bahasa Inggris di berbagai universitas, khususnya di Aceh, tempat eksperimen ini diadakan. Walaupun
\end{abstract}


para mahasiswa menunjukkan kompetensi yang baik dalam bahasa Inggris umum, mereka lemah dalam ujian skripsi. Studi ini menemukan bahwa, dengan persyaratan-persyaratan tertentu, pendekatan ini dapat memperbaiki capaian mahasiswa dalam ujian skripsi.

Kata kunci: mahasiswa S1, ujian skripsi, pendekatan genre

\section{INTRODUCTION}

Thesis defence examination (TDE) is regarded as an important event, especially for students, in many universities around the world, including Indonesia. According to Hasan (1994), different terms are given for the TDE in different countries, for example, in the USA the TDE is called an institutionalized pedagogical activity. In the UK and Australia it is called 'viva voce'. Meanwhile, in most European countries, it is named a 'public defence'. In Indonesia, it is called ujian skripsi, ujian tesis, or ujian disertasi, depending on the level of the degree. Indonesian universities offer three levels of degrees, mainly S1 (Undergraduate, four-year Batchelor), S2 (Masters), and S3 (Doctorate or $\mathrm{PhD}$ ), and those names correspond to these degrees respectively. To complete any of these degrees, they have to go through a TDE process. Otherwise, they can not graduate to have a degree.

This study focuses on TDE for undergraduate (S1) students because little research has been done on TDE at this level. All the studies found in the literature have been on TDE at the doctorate level, for example, the works of Grimshaw, Feld, and Jenness (1994), Burke (1994), Hasan (1994), Swales (2004), Morley, Leonard and David (2003) and Chen (2008). So, there is an important gap of information on such an important event awaiting attention from researchers. This gap of information is in addition to the need for further study on the possible benefit of Genre Based Approach to English Language teaching of EFL students discussed earlier, in the abstract (more on this in the literature review later).

As an Indonesian university, naturally Syiah Kuala University (Unsyiah) and the State Islamic University (UIN) require all their undergraduate students, especially the students studying in English Education Departments (EEDs). These students have to write their thesis in English. Upon completion of the thesis, they are required to deliver and defend their thesis orally in a TDE event, in front of examiners, which is also conducted using English language. Thus, students' competence in English is essential in the TDE. However, the performance of students in the TDE has been poor and has been a concern for academic staff at these universities. This concern is another factor, which triggered this study.

It is thought that the poor performance is due to the complexity of the TDE. The quality of students' oral performance in the TDE of these two universities is measured from two aspects: their understanding of research knowledge, and their presentation skills. They have to use a specific research genre language to express themselves in the presentation including in answering questions from the examiners. Hence, general English alone may not be enough to perform well; they need genre specific language, genre knowledge and presentation skills using such language because they perform in a communicative event considered as a genre in itself. A genre has a set of components that form the genre, including genre goal, norms and values, generic patterns and discipline specific terms. So, it is a goaled and staged oriented event (Swales, 1990, 2004). Genre norms may include a set of rules and procedures expected to be followed by the genre community, broadly the academic community, narrowly the community participating in the TDE such as the examiners, the head of the department, the students, and the 
secretary or administration staff, e.g. goal, generic structure, and specific terms. Genre values include things and conducts considered as good or bad used to assess performance, e.g. assessment criteria. Genre-based approach to teaching requires the presence of these components in teaching material and process (including method) so that the students can gain the genre knowledge (knowledge about the genre components) and develop the skills to perform accordingly. In other words, a group or class taught using this approach must include these components and taught with a genre appropriate method(s) so that they can perform well and meet the criteria. The central research question would be, "Do the students in a group taught using a genre-based approach perform better than those who are not?" This question is focused on the controversy regarding the possible benefit of a genre-based approach discussed at the outset. A question that specifically addresses the poor performance of undergraduate student in Aceh would be, "Can a genre-based approach help students to perform better in the TDE?

\section{LITERATURE REVIEW}

\section{Definition of Genre}

Genre has been defined in different ways by many researchers over the years. The traditional definitions of genre have focused on textual regularities (Freedman \& Medway, 2003) to differentiate the genres of heroic poems, tragedy and comedy from one another (Devitt, 1993). The definition of genre has developed from sequences of actions that writers encounter repeatedly in a particular situation, which are then defined as generic conventions because of similarities between appropriate responses that fit with the situations (Devitt, 1993; Freedman \& Medway, 2003). Genre studies in that traditional era focused on literary text and saw genres as types or kinds of discourse. More recently, there have been many genre studies that have concentrated on non-literary texts, but they still use the earlier concept of genre, that is, as 'types' or 'kinds' of discourse in relation to regularities with social and cultural activities that use language (Freedman \& Medway, 2003).

These definitions seem to be influenced by three traditions of studies of genre: first, the tradition of the new rhetoric genre (Miller, 1984); second, the tradition of systemic functional linguistics (e.g. Martin, 1984); and third, the tradition of English for specific purposes (ESP) proposed by Swales (1990). Flowerdew (2002) discusses the focus of some researchers in the new rhetoric genre and systemic functional linguistics genre traditions. According to him, the new rhetoric genre focuses on the situational context, which includes the purposes and functions of genre and attitudes, beliefs, values, and behaviours of members of discourse communities. Systemic functional linguistics researchers focus on the functional grammar and discourse, which include concentration on the lexico-grammatical and rhetorical realization of communication purposes. ESP researchers focus on detailing formal characteristics of genres and focus less on functions of text and social context (Hyon, 1996).

From the three definitions of genre above (NRG, SFL, and ESP), it is apparent that a genre includes a goal that needs to be achieved through sequential stages, following certain norms and values, and using specific terms. This definition is inspired by the definition proposed by Swales (1990) and is used for investigating TDE because it is relevant to this study based on its characteristics. 


\section{Controversy Regarding the Benefit of a Genre Approach in Teaching}

Researchers have given a great deal of attention to genre approach (GA) and its application in language teaching, but there is still some conflicting reports and views regarding its pedagogical benefit as discussed below.

According to Rose (2003), effective genre pedagogy should stress on students' habitual aptitude for selecting and adjusting genres. When students know the topic closely, they only need to adapt it to an appropriate genre. Another researcher believes that GA help students to understand a particular genre to achieve its purposes. Partridge (2004) states that the GA has a specific focus on teaching students certain genre. This might include a focus on language and discourse features or the context of the text. He suggests that the GA enables learners to use certain genres to participate in a particular genre community.

The GA helps students to enter a particular community through understanding elements of the genre. Kay and Dudley-Evants (1998) claim that the GA helps students understand the structure and purpose of texts of different genres. Texts have their own structure and purpose, so by understanding the stucture and the purpose, students could prepare themselves with strategies to achieve all elements in that particular genre.

The GA is also believed to be an appropriate teaching methodology to enable students to communicate in academic settings. Derewianka (2003), for example, states that the GA is goal-oriented and provides frameworks for students to be able to communicate. This approach is also concerned with teaching students to use language that varies systematically (Feez, 1999). In addition, Christie (1999) states that genres are useful in teaching ESL students for several reasons: firstly, they offer a principled way to identify and focus upon different types of English text by providing a clear framework to learn the features of grammar and discourse. Secondly, they offer students a sense of the generic models that are used in an English-speaking culture. Thirdly, they offer the capacity for initiating students into ways of meaning-making that are valued in English-speaking communities. Fourthly, they form a potential basis for reflecting on and critiquing the ways in which knowledge and information are organized and constructed in the English language. In short, GA could help students to achieve their purposes in communication.

However, some other researchers are not so sure of its benefit. At least two researchers are questioning about the benefit of the implementation of the GA. The first researcher is Derewianka (2003). She states that the implementation of GA has been debated by other experts, including members of the genre community. Their concerns are expressed as if the GA is feasible or it is only teachers' preferred approach to teach languages in the classroom. The second researcher is Slamet (2012). According to her, the GA fails to increase students' ability to communicate in English orally. This happens due to poor understanding about the GA concepts by teachers. Thus, selecting a certain teaching approach is not due to teachers' preference of using it; however, the understanding of its concepts is considered more important than making students competent to communicate in the target language. Hence, much more time is spent on explaining the concepts and the associated texts than developing the skills to communicate, e.g. developing text, discussing the content in the target language, and achieving their objectives using the language.

In conclusion, there is still an important controversy regarding the pedagogical benefit of the approach that needs to be investigated. The failure of the GA in significantly improving 
English language teaching in Indonesian secondary schools (TEFLIN 2011, Sukyadi, 2016) since its inclusion in the 2004 and 2006 National Curricula has further complicates the issue. This study was intended to address this controversy.

\section{Theoretical Assumption}

The theoretical assumption of this study is that to perform well in a genre specific language event, such as TDE, one should know the elements of its genre and acquired the related skills accordingly. One of the ways to introduce these elements can be done through the implementation of GA. Hence, this study investigated whether the GA can help students to perform competently in the Thesis Defence Examination (TDE) compared to the traditional non-genre approach (Communicative Language Teaching). The GA was employed in the teaching and learning process of Thesis Defence Preparation Unit (TDPU); a unit provided by Unsyiah and UIN to prepare students for a TDE. There are two TDPUs in these two universities that students have to undertake: TDPU 1, within which students learn about research writing, and TDPU 2 where students learn how to conduct a research presentation. This study will prove this assumption.

\section{Thesis Defence Examination}

Theoretically, the thesis defence examination (TDE) aims to examine the ability of students to introduce their research project, explain the results, and develop and defend their arguments. The TDE gives an opportunity for the students to show their research knowledge and presentation skills in their particular area of research. Researchers have already discussed about the purposes of the TDE in the literature, for example, Kiley (2009), Maingueneau (2002) and Jack (2002) mention that TDE aims to give opportunity for the students to deliver their research arguments and respond to examiners' questions to ensure that the students are capable of undertaking their research. During the TDE, a candidate delivers his/her work to audiences and defends the argument in order to clarify any unclear issues in the writing (Jack, 2002). Maingueneau (2002) points out that the TDE event gives opportunity to the students to show the examiners that they have enough knowledge and skills to enter their new discourse academic community.

TDE has its own generic structure (GS) that needs to be followed sequentially by students and the members of TDE. The generic structure of TDE in universities around the world is different from one to another depending on the regulation and socio culture of the universities. Some scholars have reported the generic structure of TDE in US universities (e.g. Grimshaw, Feld \& Jennes, 1994; Burke, 1994; Hasan, 1994; Swales, 2004). The GS they drew includes some segments with some activities to undertake, which may be different to the segments and activities of TDE in other universities of other countries. Therefore, students in every university are required to understand the GS of the TDE in the university they are studying. The segments and the activities under the segment usually use specific terms. Through the segments and activities as well, the examiners assess students' performance. This study assumes that it is paramount for students to understand the goal, generic structures, specific terms and assessment criteria included in the TDE genre prior to undertaking the event. This study also assumes that students can perform well only if they are introduced explicitly to the genre components of the TDE and develop the related skills as outline in a genre-based approach discussed earlier. 


\section{RESEARCH METHOD}

An experimental study was conducted by employing thirteen students, which were divided into two groups: the control and the experimental groups. The students in these two groups were divided randomly through a draw. The students in the control group were taught using the CLT approach, and the students in the experimental group were taught by the GA. Both groups also took part in a pre-test to ensure that the students were equals (Creswell, 2009). To make sure whether one group performed better than the other one, this study conducted a post-test to the Students after the treatment. Some in-depth interviews were also conducted to closely examine the results.

\section{Participants}

The criteria that students had to meet to be eligible participants for this experimental study are: 1) the students should have achieved a TOEFL score of at least 450 to indicate that the student's competence in general English is adequate, 2) the students should have passed TDPU 1 and 2, so they are familiar with the terms used in their research, have gained research knowledge and practised research presentation, 3) the students are in the process of writing their proposal or thesis, so they can practise research presentation using their own proposal or thesis, and 4) the students are eager to join this research voluntarily. The students were not paid during this research. They benefit from the activities for their future thesis defence examination. The thirteen students chosen for this study had fulfilled these four criteria.

These students were divided into two different groups randomly as suggested by Creswell (2009). To divide the students, some small rolled papers on which 'the control' or 'the experiment' was made available. The students were asked to choose one. Based on their selection, the students knew which group they belonged to. Table 1 below concludes the origin of the participants and the group they belonged to.

Table 1. Control and Experimental Group Participants

\begin{tabular}{lll}
\hline \multicolumn{1}{c}{ Group } & \multicolumn{1}{c}{ Participants } & \multicolumn{1}{c}{ Treatment } \\
\hline Control & 6 students (3 from UIN and 3 from Unsyiah) & The implementation of CLT \\
\hline Experimental & 7 students (4 from UIN and 3 from Unsyiah) & The implementation of the GA \\
\hline
\end{tabular}

\section{Instruments}

The instruments used in this study are pre-test and post-test. Three categories are assessed, these are fluency and pronunciation; grammar and vocabulary, and presentation clarity. The detail can be seen on the next section below. During the pre-test, the students presented their own research proposals or thesis topics. Thirty minutes were given to each student to talk about his or her topic in the form of an oral presentation. Each student was video recorded while doing the presentation.

\section{Data Analysis Procedures}

The students' oral presentations are analysed through the following rubric. The students' performances are graded based on their level of competence. Below is detail of score and descriptors for students' oral presentation. 
Table 2. Descriptors of Oral Presentation

\begin{tabular}{|c|c|c|c|}
\hline \multicolumn{2}{|c|}{ Research Genre English } & \multirow[t]{2}{*}{ Presentation Clarity } & \multirow[t]{2}{*}{ Score } \\
\hline Fluency and Pronunciation & Grammar and Vocabulary & & \\
\hline $\begin{array}{l}\text { Very fluent, no hesitations; } \\
\text { consistently correct } \\
\text { pronunciation and intonation, } \\
\text { easily to follow the thesis } \\
\text { arguments and evidence. }\end{array}$ & $\begin{array}{l}\text { Consistently accurate } \\
\text { reproduction, such as the use } \\
\text { of voices, words, prefixes and } \\
\text { suffixes are always correct, } \\
\text { making the flow of arguments } \\
\text { in the thesis clear and easy to } \\
\text { follow. }\end{array}$ & $\begin{array}{l}\text { Fully satisfies with } \\
\text { content of the thesis, } \\
\text { clear verbal } \\
\text { presentation and } \\
\text { response. }\end{array}$ & $\begin{array}{l}\text { 86-100 } \\
\text { (level 1) }\end{array}$ \\
\hline $\begin{array}{l}\text { Quite fluent, few hesitations; } \\
\text { generally correct } \\
\text { pronunciation and intonation, } \\
\text { quite easily to follow the } \\
\text { thesis argument and evidence. }\end{array}$ & $\begin{array}{l}\text { Almost always accurate } \\
\text { reproduction of language, such } \\
\text { as accurate use of voices, } \\
\text { words are mostly correct, } \\
\text { making the flow of arguments } \\
\text { in the thesis generally clear. }\end{array}$ & $\begin{array}{l}\text { Satisfy with the } \\
\text { content of the thesis, } \\
\text { good presentation, } \\
\text { may be found } \\
\text { irrelevant response }\end{array}$ & $\begin{array}{l}75-85 \\
\text { (level 2) }\end{array}$ \\
\hline $\begin{array}{l}\text { Fairly good fluency with some } \\
\text { hesitations; some } \\
\text { pronunciation and intonation } \\
\text { problems, but the thesis } \\
\text { arguments and evidence are } \\
\text { generally clear. }\end{array}$ & $\begin{array}{l}\text { Errors generally minor, such } \\
\text { as failure to use insignificant } \\
\text { prefixes and suffixes and } \\
\text { sentences, some words are } \\
\text { close but not accurate. }\end{array}$ & $\begin{array}{l}\text { There may be an } \\
\text { effort to explain in } \\
\text { detail of the content } \\
\text { but it fails to address } \\
\text { the questions, which } \\
\text { may have been } \\
\text { misunderstood. }\end{array}$ & $\begin{array}{l}60-74 \\
\text { (level 3) }\end{array}$ \\
\hline $\begin{array}{l}\text { A lot of hesitations; many } \\
\text { pronunciation and intonation } \\
\text { problems that make arguments } \\
\text { and evidence unclear or } \\
\text { difficult to follow. }\end{array}$ & $\begin{array}{l}\text { Frequent major errors, such as } \\
\text { wrong use of passive/active } \\
\text { voices, wrong use of } \\
\text { significant prefixes and } \\
\text { suffixes, and words. }\end{array}$ & $\begin{array}{l}\text { Fails to address the } \\
\text { thesis that may have } \\
\text { been completely } \\
\text { misunderstood, } \\
\text { presents limited ideas } \\
\text { that may be largely } \\
\text { irrelevant. }\end{array}$ & $\begin{array}{l}45-59 \\
\text { (level 4) }\end{array}$ \\
\hline $\begin{array}{l}\text { Produce little or no oral } \\
\text { performance. }\end{array}$ & $\begin{array}{l}\text { Unable to produce basic } \\
\text { sentence forms and only } \\
\text { produce isolated vocabulary. }\end{array}$ & $\begin{array}{l}\text { Answer is completely } \\
\text { unrelated to the task. }\end{array}$ & $\begin{array}{l}0-44 \\
\text { (level 5) }\end{array}$ \\
\hline
\end{tabular}

\section{Teaching Instruments and Experimental Procedures}

As discussed previously, the different groups were taught using different teaching approaches. In the control group, CLT was applied, while in the experimental group, the GA was implemented. Each group had eight teaching sessions, which took approximately three months to complete. The students from these two groups were supported by the same facilities in the classroom. During the teaching process, these two teaching methods were implemented by following the principles as found in the literature. For the control group, the students were actively speaking about their research in English. They spoke more than the lecturer during the teaching and learning process. The lecturer focused on fluency rather than grammatical errors. In the experimental group, in terms of frequency, the use of language was similar to the control group, but in the experimental group, the students were taught the TDE genre. So, the students were actively using English to practise their research knowledge and research presentation based on the TDE generic structure and values (assessment criteria) used by the examiners. 


\section{The Control Group}

In the control group, CLT was implemented in the classroom. The CLT is the teaching method that the lecturers used in teaching the students in the TDPUs at UIN and Unsyiah. CLT principles in delivering the sessions in this class were involved; for example, the students were asked to present their research proposal or thesis. The lecturer encouraged the students to use English during the teaching process. Eight meetings were conducted in this classroom.

During the teaching sessions, I acted as a facilitator to monitor the students' progress in presenting their research topics. The students were encouraged to be active, that is to speak English as frequently as possible. The students were asked to deliver their topics in front of their peers. After the presentation, the peers asked questions freely related to the research topic. The situation of the classroom was fun and encouraging because the aim of the classroom was to enable the students to use their English as much as possible. The details of teaching outline for the control group can be found in Appendix 1.

\section{The Experimental Group}

The GA principles were employed during the eight teaching sessions in the experimental class. The students were introduced to the research knowledge and presentation skills with a clear TDE genre. The TDE genre includes generic structures and values. The TDE generic structure consists of the preliminary segment, opening segment, defence proper segment, in-camera segment and closing segment. The activities in each segment were also introduced. The TDE values were the assessment criteria used by the examiners. The students in this group were given the assessment criteria form so that they could understand what the examiners expected in their presentation. As has been mentioned in this article, the TDE has its own genre, so the students were taught based on the TDE point of view to perform adequately in the TDE.

Similar to the control group, the teaching outline for the experimental group were created based on information from the students of UIN and Unsyiah. The topics of teaching were similar; however, the approach used by the teacher was different, and students did different activities when they practised the realistic TDE. Detail information about this teaching outline can be found in Appendix 2.

\section{RESULTS}

\section{Pre-test}

The pre-test aimed to find out students' competence in research presentation skills prior to experiencing a treatment. The results of the pre-test indicated that students' presentation performances in both control and experimental groups were relatively similar in the three assessment criteria: fluency and pronunciation, grammar and vocabulary, and presentation clarity (see Table 2 for the details). This similar competence can be seen from their scores, which are not significantly different.

\section{Control Group}

The following table demonstrates the results of the pre-test undertaken by the students in the control group. The coding of NUSC refers to the students from UIN in the control group, and SUSC refers to the students from Unsyiah in the control group. Each coding has a corresponding number, such as 1,2 , and 3 . These numbers refer to the individual students.

Three major aspects are given a different maximum achieved score. It is divided based on the focus of the examiners and also the level of difficulty; for example, for fluency and 
pronunciation, the highest score is 35 , for grammar and vocabulary, the highest is 15 , and for presentation clarity, the highest is 50 .

Table 3. Results of Students' Pre-test in the Control Group

\begin{tabular}{lcccc}
\hline Coding & \multicolumn{2}{c}{ Research Genre English } & Presentation Clarity & Total \\
& Fluency and Pronunciation & Grammar and Vocabulary & $(\mathbf{5 0 )}$ & $(\mathbf{1 0 0 )}$ \\
& $\mathbf{( 3 5 )}$ & $\mathbf{( 1 5 )}$ & & \\
\hline NUSC1 & 20 & 7 & 38 & 65 \\
\hline NUSC2 & 24 & 8 & 39 & 71 \\
\hline NUSC3 & 24 & 7 & 39 & 68 \\
\hline SUSC1 & 24 & 7 & 38 & 69 \\
\hline SUSC2 & 23 & 6 & 35 & 64 \\
\hline SUSC3 & 20 & 4 & 28 & 52 \\
\hline
\end{tabular}

From Table 3 above, it can be seen that the highest score was 71, which was obtained by NUSC2, and the lowest score, which was 52, was obtained by SUSC3. The gap in the scores between the highest and the lowest was 19. The lowest score for students in the pre-test is considered a passing score (The minimum passing score is 45). This score could help increase their grade point average. The score form the TDE is worth 6 credit points, which is equal to three other units. So, the higher the score the students could achieve, the better it could be for increasing their grade point average.

\section{Experimental Group}

The following table demonstrates the result of the pre-test of the students in the experimental group. The coding of NUSE refers to the student from UIN in the experimental group, and SUSE refers to the students from Unsyiah. Each coding has a corresponding number, such as 1 , 2 and 3 . These numbers also refer to the individual students.

Table 4. Results of Students' Pre-test in the Experimental Group

\begin{tabular}{|c|c|c|c|c|}
\hline \multirow[t]{2}{*}{ Coding } & \multicolumn{2}{|c|}{ Research Genre English } & \multirow{2}{*}{$\begin{array}{c}\text { Presentation Clarity } \\
\text { (50) }\end{array}$} & \multirow{2}{*}{$\begin{array}{l}\text { Total } \\
(\mathbf{1 0 0})\end{array}$} \\
\hline & $\begin{array}{l}\text { Fluency and Pronunciation } \\
\text { (35) }\end{array}$ & $\begin{array}{c}\text { Grammar and Vocabulary } \\
(15)\end{array}$ & & \\
\hline NUSE1 & 23 & 7 & 35 & 65 \\
\hline NUSE2 & 20 & 7 & 33 & 60 \\
\hline NUSE3 & 23 & 6 & 29 & 58 \\
\hline NUSE4 & 28 & 8 & 35 & 71 \\
\hline SUSE1 & 30 & 13 & 36 & 79 \\
\hline SUSE2 & 20 & 6 & 31 & 57 \\
\hline SUSE3 & 30 & 10 & 38 & 78 \\
\hline
\end{tabular}

From Table 4 above, it can be seen that the highest score was 79, which was obtained by SUSE1, and the lowest score of 57 was obtained by SUSE2. The gap in the scores between the highest and the lowest was 22. The score of 79 is considered high because it is in level 2 . The score of 57 is very low, and is in level 4 . These two selected universities adopt the highest grade point average of 4.0, so each level represents the score. Level 5 is 0.0 , level 4 is 1.0, level 3 is 2.0, level 2 is 3.0 and level 1 is 4.0 (see Appendix 1).

Tables 3 and 4 above showed the assessment criteria, including fluency and pronunciation, grammar and vocabulary, and presentation clarity with the total score of these three components is 100. Different components have different scores. 
Chart 1 below indicates the level of students' competence in the experimental and control groups of this research project. The coding of SUSE refers to students from Unsyiah in the experimental group; NUSC refers to students from UIN in the control group; NUSE refers to students from UIN in the experimental group; and SUSC refers to students from Unsyiah in the control group. A detailed explanation is provided below.

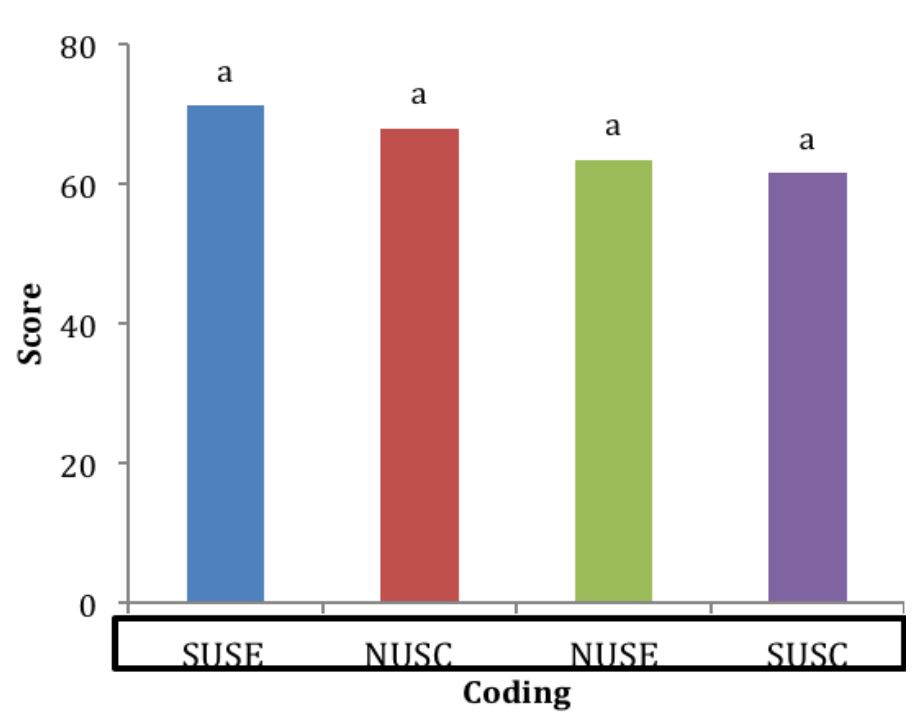

\section{Chart 1. Level of Students' Competence in the Control and Experimental Groups before Commencing the Treatment Practice}

Chart 1 above shows the dependent and independent variables of this experiment. The dependent variable is the score on the left side, and the independent variable is the coding of the students. From these variables, the competence of the students before the treatment can be clearly seen from the scores they achieved.

Chart 1 above is drawn based on the information from Table 3 and Table 5 above. Chart 1 shows the average score achieved by the students from different institutions in both the control and experimental groups. The vertical axis indicates the score for the students in the pretest and the horizontal axis explains the coding of the groups and universities. The letter (a) on the top of the graph refers to the competence of the group. As shown in the above figure, the average scores of students in the control and the experimental groups were marked with the same letter, which is ' $a$ '. This means that from the average scores, the students' competence in the verbal presentation was equal. This similar competence fulfilled one of the criteria of choosing students to participate in the experimental phase of this study. By having students with similar presentation competence, this study has avoided biased data (Creswell, 2009).

In the pre-test data, it was found that most students presented their topics without following the stages of the TDE. For example, after introducing their topics, the result was announced, followed by the research methodology and then the literature review. However, most of them did not state the gaps in their research as it is not included in their theses. These data are supported by the interview data.

\section{Post-test}

The post-test was undertaken by students in both groups, the control and experimental groups, which consisted of six students from the control group and seven students from the experimental group. To keep the identity of the students confidential, each of them was given a code or 
pseudonym. The students in these two groups presented their thesis topics for approximately thirty minutes, which was then followed by a question and answer session. The students' presentations from both groups were assessed by four qualified examiners. The assessment criteria used by the examiners was taken from the result of interviews with examiners from the two selected universities prior conducting this experimental study. The post-test was not a real TDE; however, the event was created like a real TDE. The result of this realistic TDE presentation was regarded as the student's final result for the post-test.

In this realistic test, all students from the control and experimental groups were examined. They had to pass five segments: preliminary, opening, defence proper, in-camera and closing. Four examiners were given a role; for example, examiner 1 was responsible for asking about the introduction; examiner 2 was responsible for asking about the literature review; examiner 3 was responsible for asking about the research methodology; and examiner 4 was responsible for investigating the research results. These four examiners took turns to act as an official to open the ceremony. For example, if student A presented their thesis, examiner 1 acted as an official to open the ceremony, then when student B presented their thesis, examiner 2 opened the ceremony, etc. All students were given approximately thirty minutes for the thesis presentation and ten minutes for the question and answer session. In other words, in this realistic TDE, the students were put in a real situation. The total time used for each student was forty minutes. The result of this post-test showed which of the two teaching methodologies most effectively helped students to be competent in the TDE.

\section{Control Group}

The following table shows the post-test results of the control group. The students were assessed in the same four components that were used in the pre-test: fluency and pronunciation, grammar and vocabulary, and, presentation clarity.

Table 5. Results of Students' Post-test in the Control Group

\begin{tabular}{|c|c|c|c|c|}
\hline \multirow{2}{*}{$\begin{array}{l}\text { Students' } \\
\text { Coding }\end{array}$} & \multicolumn{2}{|c|}{ Research Genre English } & \multirow{2}{*}{$\begin{array}{c}\text { Presentation } \\
\text { Clarity }\end{array}$} & \multirow[t]{2}{*}{ Total } \\
\hline & Fluency and Pronunciation & Grammar and Vocabulary & & \\
\hline NUSC1 & 27 & 6.75 & 33.7 & 67.5 \\
\hline NUSC2 & 28.7 & 11 & 35.75 & 75.5 \\
\hline NUSC3 & 27.5 & 11.25 & 35.75 & 74.5 \\
\hline SUSC1 & 27 & 11.25 & 29.75 & 68.25 \\
\hline SUSC2 & 28.5 & 11.25 & 32.75 & 54.5 \\
\hline SUSC3 & 20.5 & 6.5 & 27.75 & 54.75 \\
\hline
\end{tabular}

Table 5 above shows that the competence of the students in the control group was varied. The lowest score was 54.5 and the highest was 75.5 . The lowest score is only worth 1.0 of the 4.0 that she/he needed to achieve. With the score of 75.5 , she/he achieved a score of 3.0 out of 4.0. The final score in each section was obtained from a combination of the four results from the examiners that were divided by four.

Most comments from the examiners, as stated in their form, were that the majority of the students in the control group were shy and worried about their performance. In other words, the psychological factor still appeared in the presentation even though the students had already had some presentation practice in the control class. From the results stated in the table above, two students (SUSC1 and SUSC3) have an opportunity to re-do the examination because their score was very low. Their score indicated that they were unable to present their research with 
clear research content. They also had a lot of hesitation, which made them lack fluency. Frequent errors in grammar and inappropriate vocabulary used also commonly occurred. The students were expected to achieve 60 or above. With this score, she/he would have achieved the minimum expectation from the examiners. However, the students had to learn harder to increase their competence.

\section{Experimental Group}

The following table shows the students' post-test results in the experimental group. Three components were also used to assess the students' competence in the TDE.

Table 6. Results of Students' Post-test in the Experimental Group

\begin{tabular}{lcccr}
\hline Coding & \multicolumn{2}{c}{ Research Genre English } & Presentation Clarity & Total \\
\cline { 2 - 3 } & Fluency and Pronunciation & Grammar and Vocabulary & & \\
\hline NUSE1 & 29.75 & 11.75 & 39.25 & 80.75 \\
\hline NUSE2 & 29.5 & 12.25 & 43.5 & 85.25 \\
\hline NUSE3 & 28.5 & 9.75 & 36 & 74.25 \\
\hline NUSE4 & 30.75 & 13.5 & 44 & 88.25 \\
\hline SUSE1 & 32.75 & 12.75 & 41.75 & 87.25 \\
\hline SUSE2 & 29.75 & 10.5 & 35 & 75.5 \\
\hline SUSE3 & 30.5 & 13.25 & 42.75 & 86.5 \\
\hline
\end{tabular}

Table 6 above shows that the lowest score was 74.25 and the highest was 88.25. These scores were sufficient enough to show the students' competence. The student with the lowest score, NUSE3, had achieved in between levels 2 and 3. This means that the student had satisfied the examiners in explaining their research content as clearly as possible with minor grammatical errors, vocabulary used and with few hesitations in presenting and defending a thesis. The student with the highest score, NUSE4, had achieved the maximum expectation of the examiners. This score indicated that the student spoke with very fluent English with consistent grammar and vocabulary used. The explanation of the research content was also very clear. The scores indicate that the students' performances were good, because they achieved the expected result to pass the TDE and graduate from the university.

To compare the results of post-test obtained by students in the control and the experimental groups, a statistical tool was used and it is shown in Chart 2 below.

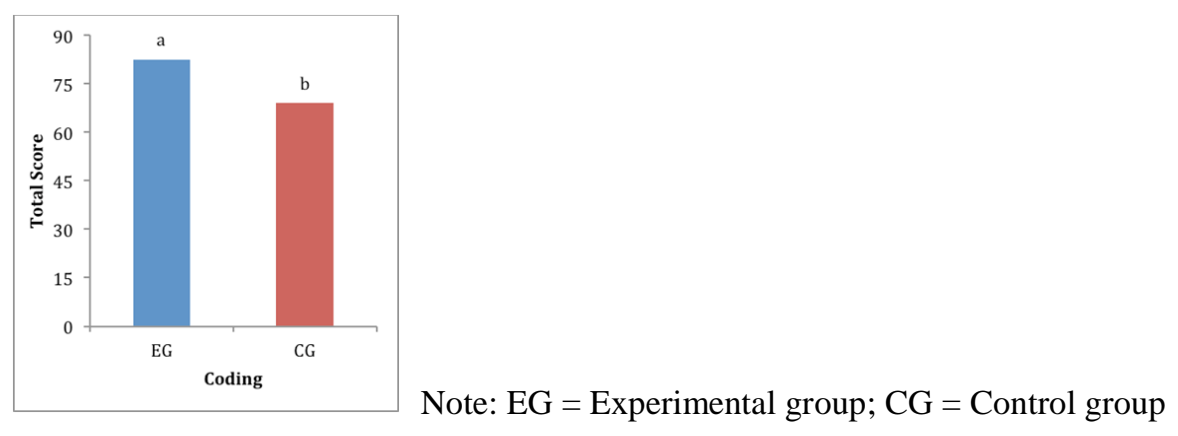

\section{Chart 2. Comparison of Post-test Results between the control and the Experimental Group}

The chart above describes three components: the total score, the coding and the letter. Each of these components has meaning. The figure shows that students in the experimental group achieved the highest scores in the posttest, gaining as much as 88.25. Meanwhile, the highest average score achieved by students in the control group is 75.5 . This indicates that students in 
the experimental group performed better in their presentation compared to students in the control group. The gap between the two averaged scores is 12.75. Based on the statistical software, the difference between the score of students in the experimental and control groups is significantly different. The significant difference can be seen from the different letter marked above each bar. The bar of the experimental group is marked with the letter a, while the bar of the control group is marked with the letter $b$. Letter a means high, and letter b means low. These different letters indicate a significant difference between the scores of the two groups in the post-test. This significant difference has been tested by the Minitab 16 statistical packet software and has also been analysed using Analysis of Variance (ANOVA). This significant difference can be seen from the letter appearing on the top of the bar chart. This significant difference also shows that the use of the GA in a TDPU can better help students to prepare for a competent presentation in the TDE, compared to the use of CLT.

Table 5, Table 6 and chart 2 above show the results of the students' post-test after having the treatment in both groups. The results indicate that the level of competence of the participants in the control and experimental groups were significantly different, where, the experimental group performed better than the control group. This significant difference occurred for several reasons, one of which is that the students of the experimental group have understood the TDE genre, while this information is absent in the control group. An understanding of the TDE genre is essential for helping students to be competent in the TDE.

The criteria in presentation clarity were closely related to how much the students understood the TDE genre. In the presentation clarity, the examiners focused on the content of the research (research knowledge) and the ability to deliver their research orally (presentation skills) and defend it. By having clear information about the TDE genre, the students know the generic structure in the TDE and also understand what the examiners expect from their presentation. So, understanding research knowledge and presentation skills with clear TDE genre could increase students' competence in the TDE. In this presentation clarity, the students in the experimental group were taught clearly through the use of the GA, while in the control group, this explanation was taught in brief and very generally. This might influence the students in the experimental group to perform better than those in the control group because of their understanding of the TDE genre. In fluency and pronunciation and grammar and vocabulary, the students' score was not significantly different.

To sum up, the post-test results have indicated that the application of the GA by introducing the TDE genre in preparing students' understanding of the research knowledge and presentation skills, when compared to the use of CLT, is more beneficial for students for improving their performance in presenting their thesis at the TDE event. The possible reason is that the GA gives more detailed information about the TDE genre and the frequent practices were based on the genre, while the CLT focuses only on the ability of the students to talk in English without introducing clearly the TDE genre. Both teaching methodologies were appropriate to help students speak fluently in English, but to be successful in the TDE, then the GA is more appropriate than CLT in the preparation units because the GA focuses on the TDE genre.

\section{DISCUSSION AND CONCLUSION}

The purpose of this study was to discover whether a genre approach can benefit student to achieve their goal, e.g. perform well in a thesis defence examination. The results of this 
experimental phase clearly indicate that the experimental group was more successful than the control group in the realistic TDE. The success and progress of the students in each group are summarised in Table 7 and Table 8 below, starting with students in the control group.

Table 7. Summary of Control Group Sudents' Scores in the Pre- and Post-tests

\begin{tabular}{|c|c|c|c|c|c|c|c|c|c|c|c|c|}
\hline \multirow[t]{3}{*}{ Student } & \multicolumn{6}{|c|}{ Research Genre English } & \multicolumn{3}{|c|}{ Presentation Clarity } & \multicolumn{3}{|c|}{ Total } \\
\hline & \multicolumn{3}{|c|}{$\begin{array}{l}\text { Fluency and } \\
\text { Pronunciation }\end{array}$} & \multicolumn{3}{|c|}{$\begin{array}{l}\text { Grammar and } \\
\text { Vocabulary }\end{array}$} & \multirow[b]{2}{*}{ Pre } & \multirow[b]{2}{*}{ Post } & \multirow[b]{2}{*}{ Note } & \multirow[b]{2}{*}{ Pre } & \multirow[b]{2}{*}{ Post } & \multirow[b]{2}{*}{ Note } \\
\hline & Pre & Post & Note & Pre & Post & Note & & & & & & \\
\hline \multirow[t]{2}{*}{ NUSC1 } & 20 & 27 & Up & 7 & 6.75 & Down & 38 & 33.7 & Down & 65 & 67.5 & Up \\
\hline & & & 7 & & & 0,25 & & & 4.3 & & & 2.5 \\
\hline \multirow[t]{2}{*}{ NUSC2 } & 24 & 28.7 & Down & 8 & 11 & Up & 39 & 35.75 & Down & 71 & 75.5 & $\mathrm{Up}$ \\
\hline & & & 4.7 & & & 3 & & & 4.75 & & & 4.5 \\
\hline \multirow[t]{2}{*}{ NUSC3 } & 24 & 27.5 & Down & 7 & 11,25 & Up & 39 & 35,75 & Down & 68 & 74,5 & Up \\
\hline & & & 3.7 & & & 4.25 & & & 4.75 & & & 6.5 \\
\hline \multirow[t]{2}{*}{ SUSC1 } & 23 & 28.5 & $\mathrm{Up}$ & 6 & 11.25 & Up & 35 & 32,75 & Down & 64 & 54,5 & Down \\
\hline & & & 5.5 & & & 5.25 & & & 3.75 & & & 9.5 \\
\hline \multirow[t]{2}{*}{ SUSC2 } & 24 & 27 & Up & 7 & 11.25 & Up & 38 & 29.75 & Down & 69 & 68.25 & Down \\
\hline & & & 3 & & & 4.25 & & & 8.25 & & & 0.75 \\
\hline \multirow[t]{2}{*}{ SUSC3 } & 20 & 20.5 & Up & 4 & 6.5 & Up & 28 & 27.75 & Down & 52 & 54.75 & $\mathrm{Up}$ \\
\hline & & & 0.5 & & & 2.5 & & & 1.75 & & & 2.75 \\
\hline
\end{tabular}

The above table shows that from the pre-test to the post-test, four students in the control group increased their score for presentation. NUSC1 added 2.5 points in the post-test to become 67.5. NUSC 2 increased 4.5 points and scored 75.5 in the post-test. NUSC 3 increased 6.5 points to 74.5 . SUSC3 was able to add 2.75 points in the post-test, which raised the score to 54.7. On the other hand, two students experienced a decrease in the post-test. SUSC1 lost as much as 9.5 points in the post-test, while SUSC2 decreased 0.75 points. Overall, most of their scores increased. The average score increased as much as 1 point from 64.8 to be 65.8 . The lowest score obtained by students in the control group were the scores in level 4, such as SUSC1 and SUSC3, which is very low. These students only obtained 1.0 out of 4.0 for their grade point average, while the highest score was placed in level 2, which was good. This student, NUSC2, obtained the score 3.0 out of 4.0 for their grade point average. Two students decreased their score in the post-test, SUSC1 and SUSC2, but others increased.

There are several possible reasons for the increased scores. Firstly, in the control group, the students had opportunities to do more presentation practices. Secondly, the students had given a lot of presentation practices with their peers in the group. These practices could be done frequently and intensively because the number of students was not as many as in their normal TDPU at their own universities. This is also related to the small number of the students in the group, which impacts on the ability of students to receive learning materials. From the score, it could also be seen that CLT is also able to increase the performance of the students in two areas, fluency and pronunciation, and grammar and vocabulary, but the score in the criteria for the presentation clarity, which is the understanding of the steps of presentation, did not increase. All students in the control group experienced a decrease in the score for the presentation clarity section. This finding indicates that students' understanding of the presentation steps (included as an element in the TDE genre) is important for increasing their score for the criteria of 
presentation clarity. The pre-test and post-test results for the experimental group are now presented.

Table 8. Score for the Pre-test and Post-test of the Experimental Group Students

\begin{tabular}{|c|c|c|c|c|c|c|c|c|c|c|c|c|}
\hline \multirow[t]{3}{*}{ Student } & \multicolumn{6}{|c|}{ Research Genre English } & \multirow{2}{*}{\multicolumn{3}{|c|}{$\begin{array}{c}\text { Presentation } \\
\text { Clarity }\end{array}$}} & \multirow{2}{*}{\multicolumn{3}{|c|}{ Total }} \\
\hline & \multicolumn{3}{|c|}{$\begin{array}{l}\text { Fluency and } \\
\text { Pronunciation }\end{array}$} & \multicolumn{3}{|c|}{$\begin{array}{c}\text { Grammar and } \\
\text { Vocabulary }\end{array}$} & & & & & & \\
\hline & Pre & Post & Note & Pre & Post & Note & Pre & Post & Note & Pre & Post & Note \\
\hline NUSE1 & 23 & 29.75 & $\begin{array}{l}\text { Up } \\
675\end{array}$ & 7 & 11,75 & $\begin{array}{l}\text { Up } \\
475\end{array}$ & 35 & 39,25 & $\begin{array}{l}\text { Up } \\
425\end{array}$ & 65 & 80,75 & $\begin{array}{l}\mathrm{Up} \\
1575\end{array}$ \\
\hline NUSE2 & 20 & 29.5 & $\begin{array}{l}\mathrm{Up} \\
9.5\end{array}$ & 7 & 12,25 & $\begin{array}{l}\mathrm{Up} \\
5.25\end{array}$ & 33 & 43,5 & $\begin{array}{l}\text { Up } \\
10.5\end{array}$ & 60 & 85,25 & $\begin{array}{l}\mathrm{Up} \\
25.25\end{array}$ \\
\hline NUSE3 & 23 & 28.5 & $\begin{array}{l}\text { Up } \\
5.5\end{array}$ & 6 & 9.75 & $\begin{array}{l}\text { Up } \\
3.75\end{array}$ & 29 & 36 & $\begin{array}{l}\text { Up } \\
7\end{array}$ & 58 & 74.25 & $\begin{array}{l}\mathrm{Up} \\
16.25\end{array}$ \\
\hline NUSE4 & 28 & 30.75 & $\begin{array}{l}\mathrm{Up} \\
2.75\end{array}$ & 8 & 13.5 & $\begin{array}{l}\mathrm{Up} \\
5.5\end{array}$ & 35 & 44 & $\begin{array}{l}\text { Up } \\
9\end{array}$ & 71 & 88,25 & $\begin{array}{l}\mathrm{Up} \\
17.25\end{array}$ \\
\hline SUSE1 & 30 & 32.75 & $\begin{array}{l}\mathrm{Up} \\
2.75\end{array}$ & 13 & 12,75 & $\begin{array}{l}\text { Down } \\
1.75\end{array}$ & 36 & 41,75 & $\begin{array}{l}\text { Up } \\
5.75\end{array}$ & 79 & 87,25 & $\begin{array}{l}\mathrm{Up} \\
8.25\end{array}$ \\
\hline SUSE2 & 20 & 29.75 & $\begin{array}{l}\mathrm{Up} \\
9.75\end{array}$ & 6 & 10.5 & $\begin{array}{l}\text { Up } \\
4.5\end{array}$ & 31 & 35 & $\begin{array}{l}\text { Up } \\
4\end{array}$ & 57 & 75.5 & $\begin{array}{l}\mathrm{Up} \\
18.5\end{array}$ \\
\hline SUSE3 & 30 & 30.5 & $\begin{array}{l}\mathrm{Up} \\
0.5\end{array}$ & 10 & 13.25 & $\begin{array}{l}\mathrm{Up} \\
3.25\end{array}$ & 38 & 42,75 & $\begin{array}{l}\text { Up } \\
3.75\end{array}$ & 78 & 86,5 & $\begin{array}{l}\text { Up } \\
8.5\end{array}$ \\
\hline
\end{tabular}

From Table 8 above, it can be seen that all students made an improvement in the total score achieved in the post-test. The majority of the students increased their score to one level above. In the pre-test, NUSE1 was in level 3, with a total score of 65 , but after undertaking the treatment in the group, his score increased as much as 15.75 to 80.75 . This score brought him to the higher level of performance, which is to level 2 according to the assessment criteria. A similar progress happened to NUSE2. She added more points compared to NUSE1 in the posttest total score by as much as 25.25 points. The total score made her performance up to level 2 . Some students, such as SUSE1 and SUSE3, levelled up their score from level 2 to level 1 by adding as much as 8.25 and 8.5 points respectively. NUSE3 commenced the experimental group with a performance marked in level 4. After the treatment, she or he levelled up his or her performance to level 3 by adding as much as 16.25 points to the post-test total score. Similarly to NUSE3, SUSE2 was also at level 4 when commencing the treatment. In the post-test, however, she lifted her performance to level 2 with an increase by as much as 18.5 points. NUSE4 started from a score marked as level 3, but at the end of the treatment he could level up his performance to level 1. Six students in the experimental group lifted their performance by one level in the post-test. Interestingly, one student, SUSE2, lifted her performance as much as two levels.

Table 8 above also indicates an increase for each assessment criteria. For fluency and pronunciation criteria, all students increased their scores. For the grammar and vocabulary criteria, only SUSE1 decreased her score by 1.75 points, while other students increased their scores on this criterion. For the criteria of presentation clarity, all students increased their scores. Overall, all students in the experimental group increased their performance in presentation clarity. The possible explanation for these results is that the students in the experimental group were aware of the TDE genre, such as the generic structure and assessment 
criteria. Because the TDE has its own genre, students who understand it could perform competently in the TDE. This understanding made it easier for the students to perform well in their TDE. The students in this experimental group knew what they had to say in the presentation; therefore, they spoke fluently with clear stages and in sequence. In addition, the students in the experimental group understood the examiners' expectations through assessment criteria in the class. This understanding brought a lot of benefit for them, such as having clear direction and less mental burden. In contrast, the control group did not show significant improvement, despite the scores in the post-test being a little higher than in the pre-test. This shows that CLT used as the teaching methodology in the control group was beneficial to help the students to speak fluently, but they failed to understand the specific genre of the TDE. The students in the control group seemed to be worried about their presentation performances because they were unsure if they did it correctly. This feeling of worry and uncertainty prevented them from performing competently.

Based on the discussion above, a conclusion can be drawn that the GA should be able to help students to perform competently in their TDE. This conclusion is drawn from the data obtained in the literature and the research results found in this experimental research. Since the TDE has its own genre, students need to understand the genre of this communicative event. Understanding the TDE genre can help students to understand the activities in every segment in the generic structures and the examiners' expectations as the values of the TDE, and prepare themselves accordingly. This understanding can also reduce their mental burden which could negatively affect their performance, e.g. nervousness. As a result, the students are able to perform competently in the TDE. From this experimental result, it can be concluded that the GA is evidently effective in the thesis defence preparation units with regard to helping student to perform competently in the real TDE. Therefore, it has reinforced the position (argument) that this approach has pedagogical benefits provided that it is properly implemented using the appropriate teaching material and teaching techniques.

\section{PEDAGOGICAL IMPLICATIONS}

The findings of this research contributes to the pedagogical implications. First, for the knowledge implication, the findings fill the defect in literature about the use of GA in preparing students to be competent in the TDE, specifically in Indonesian universities. This finding could enrich more information about the use of GA in Thesis Defence Preparation units at Indonesian universities. Second, this finding could give more ideas and information to help lecturers prepare their students who are taking thesis defence preparation units, called Research on ELT and Seminar on ELT at these two universities.

\section{SUGGESTION FOR FURTHER RESEARCH}

This study has addressed the controversy regarding the pedagogical benefits of Genre Approach from the perspective of English for Specific Purposes. However, it has some limitations including its restricted number of participants, restricted number of universities being included, and the restricted level of study (undergraduate only), to say just a few. Due to these limitations further research still needs to be conducted to settle the important controversy. For example, researchers can do similar research employing a bigger number of participants and involving higher number of universities. Research could also be conducted at Masters (S2) level. 


\section{NOTE}

* We would like to thank an anonymous reviewer for very helpful comments on the earlier draft. We also would like to thank Dr. Kiyomi Yamada and Ruth Nicholls for their comments on the earlier draft of the manuscript. A major appreciation is expressed to the two universities for allowing this study to go ahead and their staff for their help with crucial information. Special thanks go to the students who were willing to volunteer for the experiment and the subsequest interviews. Very special thanks go to Dr. Siti Sarah Fitriani for her help during the study process and comments on the manuscript.

\section{REFERENCES}

Chen, S. (2008). The Ph.D. dissertation defence in Canada: An institutional policy perspective. Canadian Journal of Educational Administration and Policy 88(22), 1-24.

Christie, F. (1999). Genre theory and ESL teaching: A systemic functional perspective. TESOL Quarterly, 33 (Winter), 759-763.

Creswell, J. W. (2009). Research design: Qualitative, quantitative, and mixed methods approaches $\left(3^{\text {rd }}\right.$ ed.). Los Angeles: Sage.

Devitt, A. J. (1993). Generalizing about genre: New conceptions of an old concept. College Composition and Communication, 573-586.

Derewianka, B. (2003). Trends and issues in genre-based approaches. RELC Journal, 34(2), 133-154.

Feez, S. (1999). Text-based syllabus design. TESOL in Context, 9(1), 11.

Flowerdew, J. (2002). Genre in the classroom: A linguistic approach. Genre in the classroom: Multiple perspectives, 91-102.

Freedman, A. \& Medway, P. (2003). (eds.) Genre and the new rhetoric. London: Taylor \& Francis.

Hasan, R. (1994). Situation and the definition of genres. In D. G. Allen (ed.), What's going on here?: Complementary studies of professional talk (pp. 127-167). Norwood, NJ: Ablex Publishing Corporation.

Hyon, S. (1996). Genre in three traditions: Implications for ESL. Tesol Quarterly, 693-722.

Jack, B. (2002). The final hurdle: Preparation for the PhD viva examination. Nurse Researcher, 10(2), 66.

Kay, H. \& Dudley-Evans, T. (1998). Genre: What teachers think. ELT Journal, 52(4), 308-314.

Kiley, M. (2009). Rethinking the Australian doctoral examination process. AUR, 32.

Maingueneau, D. (2002). Analysis of an academic genre. Discourse studies, 4(3), 319-341.

Martin, J. R. (1985). Language, register, and genre. Children writing reader. Deakin University Press.

Miller, C. R. (1984). Genre as social action. Quarterly Journal of Speech, 70(2), 151-167.

Morley, L., Leonard, D., \& David, M. (2003). Quality and equality in British Ph.D. assessment. Quality Assurance in Education, 11, 64-72. 
Paltridge, B. (2004). Approaches to teaching second language writing. Paper presented at the $17^{\text {th }}$ Educational Conference, Adelaide.

Rose, D. (2003). Speaking. In Ronald Carter \& David Nunan. Teaching English to speakers of other languages. Cambridge: Cambridge University Press.

Slamet, S. (2012). Efektifitas pembelajaran keterampilan speaking dengan pendekatan genre di Universitas Muhammadiyah Surakarta. Varia Pendidikan, 24(1), 50-58.

Sukyadi, D. (2015). The teaching of English in Indonesia. In B. Spolsky and K. Sung (eds.), Secondary school English education in Asia: From policy to practice. London \& New York: Routledge.

Swales, J. M. (1990). Genre analysis: English in academic and research writing. Cambridge: Cambridge University Press.

TEFLIN (2011). Pernyataan kebijakan tentang pengajaran bahasa Inggris di Indonesia. Bandung: TEFLIN. 
Appendix 1. The Teaching Outline for the Control Group

\begin{tabular}{|c|c|c|}
\hline No. of Meeting & Topics of Teaching & Activities \\
\hline 1 & Introducing sections of thesis & $\begin{array}{l}\text { Free presentation of: } \\
\text { Background of research } \\
\text { Research problems } \\
\text { Research questions or hypotheses } \\
\text { Aims of research } \\
\text { Literature review } \\
\text { Method of data collection } \\
\text { Research results } \\
\text { Conclusion }\end{array}$ \\
\hline 2 & $\begin{array}{l}\text { Introducing the TDE at two } \\
\text { selected universities in } \\
\text { Indonesia }\end{array}$ & $\begin{array}{l}\text { Describing general information about the TDE at } \\
\text { Nanggroe University and Syiar University }\end{array}$ \\
\hline 3 & Group presentation & \multirow{6}{*}{$\begin{array}{l}\text { Students present their research topic and } \\
\text { other students ask questions about the topic }\end{array}$} \\
\hline 4 & Individual presentation & \\
\hline 5 & Group presentation & \\
\hline 6 & Individual presentation & \\
\hline 7 & Group presentation & \\
\hline 8 & Individual presentation & \\
\hline
\end{tabular}

\section{Appendix 2. Teaching Outline for the Experimental Group}

\begin{tabular}{|c|c|c|}
\hline No. of Meeting & Topics of Teaching & Activities \\
\hline 1 & $\begin{array}{l}\text { Introducing sections of } \\
\text { thesis }\end{array}$ & $\begin{array}{l}\text { An explanation of the: } \\
\text { Background of research } \\
\text { Research problems } \\
\text { Research questions or hypotheses } \\
\text { Aims of research } \\
\text { Literature review } \\
\text { Method of data collection } \\
\text { Research results } \\
\text { Conclusion }\end{array}$ \\
\hline 2 & $\begin{array}{l}\text { Introducing the TDE at } \\
\text { two selected universities in } \\
\text { Indonesia }\end{array}$ & $\begin{array}{l}\text { Describing general information of the TDE at } \\
\text { Nanggroe University and Syiar University }\end{array}$ \\
\hline 3 & Introducing the TDE genre & $\begin{array}{l}\text { Introducing: } \\
\text { the generic structure of the TDE, } \\
\text { the steps of thesis presentation, } \\
\text { the role of the committee members. } \\
\text { Values: the assessment criteria }\end{array}$ \\
\hline 4 & Realistic TDE 1 & \multirow{5}{*}{$\begin{array}{l}\text { Students present their research topic based on } \\
\text { sections of thesis and others ask questions to test } \\
\text { the presenter based on the assessment criteria }\end{array}$} \\
\hline 5 & Realistic TDE 2 & \\
\hline 6 & Realistic TDE 3 & \\
\hline 7 & Realistic TDE 4 & \\
\hline 8 & Realistic TDE 5 & \\
\hline
\end{tabular}

